\title{
BRAZILIAN-PORTUGUESE VERSION AND APPLICABILITY QUESTIONNAIRE OF THE MOBILITY INDEX FOR ANKYLOSING SPONDYLITIS
}

\author{
Samuel Katsuyuki Shinjo, Roberta Gonçalves, Sérgio Kowalski, Célio Roberto \\ Gonçalves
}

\begin{abstract}
Shinjo SK, Gonçalves R, Kowalski S, Gonçalves CR. Brazilian-Portuguese version and applicability questionnaire of the mobility index for ankylosing spondylitis. Clinics. 2007;62(2):139-44.
\end{abstract}

PURPOSE: To translate and adapt the Bath Ankylosing Spondylitis Methodology Index (BASMI) - a metrological measurement for the assessment of patients with ankylosing spondylitis to Brazilian-Portuguese and to analyze the applicability of the questionnaire. METHODS: The Brazilian-Portuguese version of the Bath Ankylosing Spondylitis Methodology Index was achieved through a translation and back-translation process. This new Bath Ankylosing Spondylitis Methodology Index version was administered to 25 consecutive patients with ankylosing spondylitis who met the 1984 New York criteria for ankylosing spondylitis and were followed in the Soronegative Spondyloarthropathy Unit of the Rheumatology Division, São Paulo University Medical School, from May to November 2005. In order to evaluate the applicability of the questionnaire, it was administered to patients by 2 separate observers, A and B (Rheumatologists), enabling inter-observer test analysis. After 2 weeks, the second interview was administered to the same patients by observer A only to analyze the intra-observer test. All interviews were conducted in the morning. The Pearson coefficient correlation was used to evaluate applicability.

RESULTS: There was no conflict stemming from translation and re-translation of Bath Ankylosing Spondylitis Methodology Index questionnaire, and cross-cultural adaptation proved unnecessary. All components had statistically significant coefficients for intra- and inter-observational applicability, with scores ranging from 0.85 to 1.00 and 0.80 to 0.94 , respectively.

DISCUSSION: The Brazilian-Portuguese version of the Bath Ankylosing Spondylitis Methodology Index proved to be an applicable instrument for analyzing the mobility index of Brazilian patients with ankylosing spondylitis.

KEYWORDS: Ankylosing spondylitis. Mobility. Portuguese. Questionnaire. Translation.

\section{INTRODUCTION}

Ankylosing spondylitis (AS) is a chronic and systemic inflammatory osteoarticular disease. The status of disease can be defined by laboratory, radiologic, and metrologic variables, as well as through functional capacity ${ }^{1}$ and disease activity. ${ }^{2,3}$ However, correlation among these variables, disease progression, and therapy success have not yet been defined. ${ }^{4}$

Soronegative Spondyloarthropathy Unit, Rheumatology Division, São Paulo University Medical School - São Paulo/SP, Brazil.

Email: samuel.shinjo@gmail.com

Received for publication on July 19, 2006.

Accepted for publication on November 01, 2006.
The use of laboratory markers for acute stages of the disease has remained controversial, as correlation between disease activity and laboratory markers is not always evident. ${ }^{4}$ No single laboratory exam can establish AS diagnosis, but exams are nonetheless helpful for monitoring the level of inflammatory activity. Alterations are not specific; the patients may show anemia, as well as higher levels of alkaline phosphatase and creatine-phosphokinase. The most frequently used exams for diagnosis and follow-up of AS are: (a) erythrocyte sedimentation rate, which in most patients is higher in the acute disease stage and (b) C-reactive protein, for which the association with disease activity is more controversial. ${ }^{5}$

Since the 1990s, questionnaires have been developed to 
measure disease activity: the Bath Ankylosing Spondylitis Disease Activity Index (BASDAI), ${ }^{2,3}$ functional capacity evaluation, ${ }^{6,7}$ radiologic findings (The Bath Ankylosing Spondylitis Radiology Index, BASRAI) ${ }^{8}$ metrologic measurements (The Bath Ankylosing Spondylitis Metrology Index, BASMI), ${ }^{9}$ global status (The Bath Ankylosing Spondylitis Global Score, BAS-G), ${ }^{10}$ and quality of life (Health Quality of Life). ${ }^{11,12}$

Regarding the mobility index, there are more than 20 different assessments are available for disease evaluation. However, Jenkinson et $\mathrm{al}^{9}$ devised 5 minimum measurements, which form the BASMI, as follows: cervical rotation, wall-tragus distance, lumbar lateral flexion, modified Schöber index, and maximum intermalleolar distance.

Cervical rotation occurs at the atlantoaxial joint, being a reproducible measurement reflecting the importance of neck function. ${ }^{13}$ Wall-tragus distance is a measurement of lower cervical spine flexion and upper thoracic kyphosis. It provides an accurate assessment of proximal axial disease progression and is highly reproducible. ${ }^{14}$ Lateral spinal flexion occurs at the lower thoracic and the lumbar spine and is often the earliest restricted movement in AS. ${ }^{15}$ The modified Schöber index ${ }^{16,17}$ measures vertebral flexion. Intermalleolar distances assess hip and pelvic soft tissues.

Each of these parameters is scored between 0 and 2, depending on the disease involvement ( 0 : mild, 1 : moderate, 2: severe disease involvement). The sum of all measurement scores on the evaluation questionnaire is divided by 5 , giving the BASMI value with a final score ranging from 0 to 2 .

In order to use the instrument internationally, this questionnaire should first be translated into the native country language and then adapted to the culture. Moreover, its measurement capacity should be evaluated after the translation and cultural adaptation process, in order to guarantee that the new version of the questionnaire has the same efficacy as the original.

Hitherto, no Brazilian-Portuguese versions of AS disease measuring instruments had been available, especially any covering the metrological aspects. The aim of the present work was to translate and adapt the BASMI into a Brazilian-Portuguese version.

\section{MATERIALS AND METHODS}

Patients. We analyzed 25 patients with AS from the Soronegative Spondyloarthropathy Unit of the Rheumatology Division, São Paulo University Medical School, from May to November 2005. All analyzed patients fulfilled the modified New York criteria for $\mathrm{AS}^{18}$ and were clinically stable, having signed informed consent forms.
The translation of the BASMI from English to Brazilian-Portuguese and its adaptation to Brazilian culture were performed according to international recommendation criteria. $^{19}$

Translation to Brazilian-Portuguese. The BASMI was initially translated independently into Portuguese by 2 Brazilian teachers of English, who were informed about the purpose of the present study. The 2 versions (V1 and V2) were compared, and after consensus amongst the translators and one of the authors of the current work (Rheumatologist), the first draft of the Brazilian-Portuguese version was produced (V12).

Re-translation. The first version in Brazilian-Portuguese (V12) was then retranslated back into English twice (R1 and R2) by 2 teachers who were native speakers of English and blind to the purpose of the study. Subsequently, a comparison was made among the 2 back-translated versions (R1 and R2) and the original instrument in English in order to remedy any arising discrepancies.

Applicability evaluation. The applicability of the Brazilian-Portuguese version of the BASMI was evaluated through 3 interviews by 2 set observers: A and B (Rheumatologists). Two evaluations were made independently by observers A and B on the same day. Two weeks after the first interview, a second evaluation was made by observer A. All interviews were conducted in the morning period.

Questionnaire administration. (a) Evaluation of cervical rotation, based on joint motion: ${ }^{20}$ patient lies in neutral position and the goniometer is placed centrally on the forehead. The patient is then asked to turn their head as far as possible to the right and then to the left; (b) Tragus to wall distance, according to Tomlinson et al: ${ }^{14}$ the patients stands with heels and buttocks touching the wall, knees straight, shoulders back and places the head as far back as possible, keeping the chin in; (c) Lateral lumbar flexion, according to Pile et $\mathrm{al}^{.21}$ the same starting position as for the wall-tragus distance Initially, the upper limb is extended, without spine orientation, and the distance between finger extremities and floor is obtained. The ventral part of the hand is then extended to the lateral part of the thigh, and patient is instructed to move their hand in the direction of the floor, bending the spine laterally. Another measurement of the distance between extremities of fingers and the floor is taken. The difference between the 2 measurements constitutes the lateral flexion spine measurement. This process is repeated on the other side. (d) lumbar flexion, according to Macrae \& Wrigh: ${ }^{16}$ the same patient position as the previous test, but the observer, far from the wall, marks the first point between the posterosuperior iliac spine, while the second point is marked $10 \mathrm{~cm}$ above this, 
and the third $5 \mathrm{~cm}$ below the first, creating a $15-\mathrm{cm}$ line with 3 points. The patient flexes the column forwards, with the knee extended. The distance between the superior and inferior point is measured, where a measurement of more than $15 \mathrm{~cm}$ is considered normal. (e) Intermalleolar distance, according to Calin: ${ }^{22}$ the patient, in supine position with knees straight and feet pointing straight up, is asked to separate the legs as far as possible, and the distance between the medial malleoli is measured.

All 5 scores obtained from the evaluation questionnaire are added, and the total is divided by 5 to obtain the BASMI value.

Statistical analysis. The Pearson coefficient was used to evaluate the intra and inter-observer applicability of the questionnaire. A $P$ value $<0.05$ was considered statistically significant.

\section{RESULTS}

The translated questionnaire was administered to 25 patients with AS. Table 1 shows the demographic and clinical features of population study sample. The mean age \pm standard deviation (SD) was $52.0 \pm 13.5$ years, with male gender predominance (21 patients, $84 \%$ ). The mean age \pm $\mathrm{SD}$ at onset of clinical symptoms was $36.0 \pm 5.5$ years, with mean disease duration of 16 years. All patients showed radiologic alteration of sacroiliac articulations. Out of those diagnosed with AS, 17 (68\%) patients presented radiologi-

Table 1 - Laboratory and demographic features of 25 consecutive patients with ankylosing spondylitis

\begin{tabular}{|c|c|c|}
\hline \multicolumn{2}{|c|}{ Demographic and laboratory features } & $\mathrm{n}=25$ \\
\hline \multicolumn{2}{|c|}{ Mean of age \pm Standard deviation (years) } & $52.0 \pm 13.5$ \\
\hline Male sex $(\%)$ & $21(84)$ & \\
\hline \multirow[t]{2}{*}{ Ethnic } & White (\%) & $20(80)$ \\
\hline & Black (\%) & $5(20)$ \\
\hline \multicolumn{2}{|c|}{ Initial of disease (mean of age $\pm \mathrm{SD}$ : years) } & $36.0 \pm 5.5$ \\
\hline \multirow[t]{5}{*}{ Alteration } & cervical (\%) & $6(24)$ \\
\hline & thoracic $(\%)$ & $1(4)$ \\
\hline & lumbar $(\%)$ & $17(68)$ \\
\hline & peripheral $(\%)$ & $8(32)$ \\
\hline & ocular (uveitis) (\%) & $4(16)$ \\
\hline \multirow[t]{6}{*}{ Medications } & Nothing $(\%)$ & $6(24)$ \\
\hline & Sulphasalazine (\%) & $15(60)$ \\
\hline & Methotrexate $(\%)$ & $7(28)$ \\
\hline & Infliximab $(\%)$ & $3(12)$ \\
\hline & Azathioprine (\%) & $1(4)$ \\
\hline & Cyclosporin $(\%)$ & $1(4)$ \\
\hline \multirow[t]{3}{*}{ Medicine } & Nothing $(\%)$ & $6(24)$ \\
\hline & Monotherapy (\%) & $14(56)$ \\
\hline & Two or more medicine $(\%)$ & $5(20)$ \\
\hline \multicolumn{2}{|c|}{ Hemoglobin (mg/dL) } & $14.2 \pm 0.4$ \\
\hline \multicolumn{2}{|c|}{ Albumin (mg/dL) } & $3.6 \pm 0.1$ \\
\hline \multicolumn{2}{|c|}{ Creatinine (mg/dL) } & $0.9 \pm 0.3$ \\
\hline \multicolumn{2}{|c|}{ Hemo sedimentation rate $(\mathrm{mm} / \mathrm{h})$} & $11.9 \pm 2.6$ \\
\hline \multicolumn{2}{|c|}{ C-reactive protein (mg/dL) } & $9.4 \pm 1.6$ \\
\hline
\end{tabular}

cal alteration and clinical manifestations of the lumbar segment, 6 (24\%) of the cervical column; 25 (100\%) of the sacroiliac; $13(52 \%)$ of the hip; $8(32 \%)$ presented peripheral alterations, and $3(12 \%)$ presented enthesitis.

Adaptation of the Brazilian-Portuguese version of the BASMI (Table 2) to the local culture was unnecessary, since it was based on the metrological evaluation.

Table 2 - Questionnaire, The Bath Ankylosing Spondylitis Metrology, in the original version and in the version translated into the Brazilian-Portuguese language

Índice Metrológico de Espondilite Anquilosante (The Bath Ankylosing Spondylitis Metrology Index)

\begin{tabular}{lccc}
\hline & \multicolumn{3}{c}{ Pontuação (Score) } \\
& 0 & 1 & 2 \\
\hline $\begin{array}{l}\text { Distância parede-trago } \\
\text { Wall-tragus distance }\end{array}$ & $<15 \mathrm{~cm}$ & $15 \sim 30 \mathrm{~cm}$ & $>30 \mathrm{~cm}$ \\
$\begin{array}{l}\text { Flexão lombar } \\
\text { Lumbar flexion }\end{array}$ & $>4 \mathrm{~cm}$ & $2 \sim 4 \mathrm{~cm}$ & $<2 \mathrm{~cm}$ \\
$\begin{array}{l}\text { Rotação cervical } \\
\text { Cervical rotation }\end{array}$ & $>70^{\circ}$ & $20 \sim 70^{\circ}$ & $<20^{\circ}$ \\
$\begin{array}{l}\text { Flexão lombar lateral } \\
\text { Lumbar side flexion } \\
\text { Distância intermaleolar } \\
\text { Intermalleolar distance }\end{array}$ & $>10 \mathrm{~cm}$ & $5 \sim 10 \mathrm{~cm}$ & $<5 \mathrm{~cm}$ \\
\hline
\end{tabular}

The inter- and intra-observer applicability, analyzed by Pearson correlation coefficient, showed a satisfactory result (Table 3), ranging from 0.85 to 1.00 (intra-observational test) and 0.90 to 0.96 (inter-observational test).

Table 3 - Evaluation of intra and inter-observational applicability of the BASMI Brazilian-Portuguese version

\begin{tabular}{lcc}
\hline Measurement (parametric) & r value & $P$ value \\
\hline Intra-observational & & \\
Wall-tragus distance & 1.00 & $<0.05$ \\
Lumbar flexion & 0.85 & $<0.05$ \\
Cervical rotation & 0.90 & $<0.05$ \\
Lumbar side flexion & 1.00 & $<0.05$ \\
Intermalleolar distance & 0.96 & $<0.05$ \\
& & \\
Inter-observational & & $<0.05$ \\
Wall-tragus distance & 0.94 & $<0.05$ \\
Lumbar flexion & 0.90 & $<0.05$ \\
Cervical rotation & 0.91 & $<0.05$ \\
Lumbar side flexion & 0.92 & $<0.05$ \\
Intermalleolar distance & 0.96 & \\
\hline
\end{tabular}

\section{DISCUSSION}

There is no gold standard of laboratory or clinical measurement to evaluate AS across different clinical aspects. The use of laboratory markers in acute stages of the dis- 
ease remains controversial because of the possibility of no correlation between activity and disease progression. ${ }^{1}$

Since the 1990s, serial questionnaires have been developed to measure AS disease status in different aspects (activity, functional capacity, radiological findings, metrological measures, global status, and quality of life). However, these instruments have not been made available in Brazilian-Portuguese to evaluate Brazilian AS patients and allow comparison of results across different studies, particularly for natural disease history and therapeutic intervention variables.

In the present work, we translated the BASMI into a Brazilian-Portuguese version. There was no conflict in translation and re-translation of the original version of BASMI, and there no need for cultural re-adaptation, by virtue of its exclusively medical and technical terminology content. Moreover, the applicability of the translated questionnaire showed good correlation both in intra-observational and inter-observational tests.

Since there is no gold-standard questionnaire able to correlate with different stages of the disease, questionnaire applicability validation is hampered. Jones et al, ${ }^{10}$ for example, correlated BASMI with BAS-G results and obtained negative correlation of 0.16 . Kennedy et $\mathrm{al}^{23}$ correlated radiological scores with 5 points on the BASMI, obtaining low correlation values between $30 \%$ and $50 \%$. The low cor- relation could be explained by other factors such as purely radiological alterations, physical limitation, soft tissue, and enthesopathic lesion alterations. Moreover, disease activity at the time of measurement by BASMI may not have corresponded to radiological findings.

BASMI validation could be possible, for example, by administering the questionnaire to a group of patients with initial or progressive disease stages, and with or without physiotherapeutic treatment. However, the difficulty in obtaining sufficient patients not undergoing physiotherapy treatment is a limiting factor.

In the present work, a prospective study of metrological evaluation to validate the Brazilian-Portuguese version of the BASMI was not carried out because patients analyzed had been diagnosed with AS for more than 18 years. Furthermore, the majority of patients had reached disease sequelae stages, apart from having been submitted to physiotherapy treatment, thereby making metrological analysis difficult. Nonetheless, it should be noted that the present study was a pilot test that confirmed the applicability of the Brazilian-Portuguese version of BASMI in our environment.

Further studies with more patients at earlier stages of $\mathrm{AS}$, or with a longer duration and activity period of the disease should be conducted in order to validate the present Brazilian-Portuguese version of the BASMI.

\section{RESUMO}

Shinjo SK, Gonçalves R, Kowalski S, Gonçalves CR. Versão em língua portuguesa do Brasil e a reprodutibilidade do questionário de índice de mobilidade para espondilite anquilosante. Clinics. 2007;62(2):139-44.

OBJETIVO: Traduzir e adaptar para a língua portuguesa do Brasil o Bath Ankylosing Spondylitis of Metrodology Index (BASMI) - instrumento de mensuração metrológica de pacientes com espondilite anquilosante - além de avaliar a reprodutibilidade deste questionário.

MÉTODOS: O Bath Ankylosing Spondylitis of Metrodology Index em versão língua portuguesa do Brasil foi obtida após processo de tradução e retro-tradução. Essa nova versão foi aplicada em 25 pacientes consecutivos com espondilite anquilosante, que preenchiam os critérios modificados de Nova Iorque de 1984 e que estavam em acompanhamento na Unidade de Espondiloartropatia Soronegativa do Serviço de Reumatologia da Faculdade de Medicina de Universidade de São Paulo, de maio a novembro de 2005. Para avaliar a reprodutibilidade, o questionário foi aplicado aos pacientes por dois observadores fixos e independentes: A e B (Reumatologistas), no mesmo dia, para avaliar teste interobservador. Após 14 dias, o observador A reaplicou o questionário aos mesmos pacientes para avaliação de teste intra-observador. Todas as entrevistas foram feitas no período de manhã. $O$ coeficiente de correlação de Pearson foi usado para avaliação da reprodutibilidade.

RESULTADOS: Não houve conflito quanto a tradução e 
re-tradução do questionário Bath Ankylosing Spondylitis of Metrodology Index. Também não houve a necessidade de adaptação cultural. Todos os componentes do Bath Ankylosing Spondylitis of Metrodology Index apresentaram coeficiente estatisticamente significante para reprodutibilidade intra e interobservadores, com escores, respectivamente, variando entre 0,85 a 1,00, e 0,80 a 0,94. DISCUSSÃO: O Bath Ankylosing Spondylitis of Metrodo- logy Index, versão para a língua portuguesa do Brasil, mostrou-se ser um instrumento reprodutível para ser utilizado na avaliação do índice de mobilidade de pacientes brasileiros com espondilite anquilosante.

UNITERMOS: Espondilite anquilosante. Mobilidade. Português. Questionário. Tradução.

\section{REFERENCES}

1. Rigby AS, Silman AJ. Editorial outcome assessment in clinical trials of AS. Br J Rheumatol. 1991;30:321-2

2. Garret S, Jenkinson T, Kennedy LG, Whitelock H, Gaisford P, Calin A. A new approach to defining disease status in ankylosing spondylitis: the Bath Ankylosing Spondylitis Disease Activity Index. J Rheumatol. 1994;21:2286-91

3. Calin A, MackaYK, Santos H, Brophy S. A new dimension to outcome application of the Bath Ankylosing Spondylitis Radiology Index. J Rheumatol. 1999;26:988-92.

4. Taylor HG, Wardle T, Beswick E.J, Dawes PT. The relationship of clinical and laboratory measurements to radiological change in AS. Br J Rheumatol. 1991;30:330-5.

5. Ruof J, Stuck G. Validity aspects of erythrocyte sedimentation rate and C-reactive protein in ankylosing spondylitis. A literature review. J Rheumatol. 1999;26:966-70.

6. Dougados M, Guegue NA, Nakache JP, Nguyen M, Amor B. Evaluation of a function index for patients with ankylosing spondylitis. J Rheumatol.1990;17:1254-5.

7. Calin A, Garret S, Whitelock H, Kennedy G, O'Hea J, Mallorie P et al A new approach to defining functional ability in ankylosing spondylitis: the development of the Bath Ankylosing Spondylitis Functional Index. J Rheumatol. 1994;21:2281-5.
8. Mackay K, Mack C, Brophy S, Calin A. The Bath Ankylosing Spondylitis Radiology Index: a new validated approach to disease assessment. Arthritis Rheum. 1998;41:2263-370.

9. Jenkinson T, Malloric PA, Whitelock HC, Kennedy, LG, Garret SL, Calin A. Defining spinal mobility in ankylosing spondylitis: The Bath Ankylosing Spondylitis Metrology Index (BASMI). J Rheumatol. 1994;21:1694-8

10. Jones SD, Steiner A, Garrett SL, Calin A. The Bath Ankylosing Spondylitis Global Score (BAS-G). Br J Rheumatol. 1996;35:66-71.

11. Daltroy LH, Larson MG, Roberts NW, Liang MH. A modification of the Health Assessment Questionnaire for the spondyloarthropathies. J Rheumatol. 1990;17:946-50.

12. Doward LC: Development of the ASQol: a quality of life instrument specific to Ankylosing Spondilitis. Ann Rheum Dis. 2003;62:20-6.

13. Moffet JAK, Hughes I, Griffiths P. Measurement of cervical spine movements using a simple inclinometer. Phys Ther. 1989;75:309-12.

14. Tomlinson MJ, Bareffot J, Dixon A ST J. Intensive in-patient physiotherapy courses improve movement and posture in ankylosing spondylitis. Physiotherapy. 1986;72:238-40.

15. Moll JMH, Liyanage SP, Wright V. An objective clinical method to measure lateral spinal flexion. Rheum Phys Med. 1972;11:225-39. 
16. Macrae IF, Wright V. Measurement of back movement. Ann Rheum Dis. 28: 584-9, 1969.

17. Schöber Von P. The lumbar vertebral column and backache. Murch Med WSCW. 1937;84:336-8.

18. Van der Linden S, Valkenburg HA, Cats A. Evaluation of diagnostic criteria for ankylosing spondylitis. A proposal for modification of the New York criteria. Arthritis Rheum. 1984;4:361-8.

19. Guillemin F, Bombardier C, Beaton D. Cross-cultural adaptation of health-related quality of life measures: literature review and proposed guidelines. J Clin Epidemiol. 1993;12:1417-32.
20. Joint motion: Methods of measuring and recording. Chicago IL. American Academy of Orthopaedic Surgeons. 1965;44-64.

21. Pile KD, Laurent MR, Salmond CE, Best MJ, Pyle EA, Moloney RO Clinical assessment of ankylosing spondylitis. A study of observer variation in spinal measurements. Br J Rheum. 1991;30:29-34.

22. Calin A: Ankylosing spondylitis. In: Textbook of Rheumatology, $2^{\text {nd }}$ edn. Kelly WN, Harris ED, Ruddy S, Sledge CB, editors. Philadelphia: WB Saunders; 1985. p.993

23. Kennedy LG, Jenkinson TR, Mallorie PA, Whitelock HC, Garrett SL, Calin A. Ankylosing spondylitis: the correlation between a new metrology score and radiology. Br J Rheumatol. 1995;8:767-70. 